\title{
Dynamics of macrofaunal body size in a deltaic environment
}

\author{
Ioanna Akoumianaki ${ }^{1,3, *}$, Sokratis Papaspyrou ${ }^{2}$, Artemis Nicolaidou ${ }^{2}$ \\ ${ }^{1}$ Department of Biology, University of Crete, Vassilika Vouton, 71409 Heraklio, Crete, Greece \\ ${ }^{2}$ Department of Zoology-Marine Biology, University of Athens, Panepistimiopolis 15784, Athens, Greece \\ ${ }^{3}$ Present address: Institute of Oceanography, Hellenic Centre for Marine Research, Anavissos 19013, Attiki, Greece
}

\begin{abstract}
Macrofaunal density, biomass, and respiration size spectra, as well as density- and respiration-body size allometries, were investigated in a deltaic environment of the eastern Mediterranean (Maliakos Gulf, Greece). Four stations were sampled along a gradient of increasing depth and decreasing water transparency from the river mouth to the plume area in May, August, and November 2000, and February and May 2001. Density and biomass significantly decreased in winter and spring near the river mouth. The shape and peaks of size spectra were temporally variable, indicating that no single factor determines body size at all times. The slopes of the seasonally averaged normalized biomass size spectra gradually decreased from -0.47 at the river mouth to -1.03 in the plume area, clearly indicating a biomass increase with increasing body size towards the river mouth. A flat lower boundary in density/body size relationships at all stations precluded a strong negative regression slope and indicated that the density of small- and intermediate-sized macrofaunal organisms is constrained by perturbations. Regressions of calculated respiration rates against body size were close to 0.75 only at the river mouth during winter, thus indicating that increases in riverine sediment discharges during that period constrain the macrofaunal community. Overall, there was no evidence of energy supply constraints for macrofaunal body size in Maliakos Gulf. Irrespective of whether size spectra and body size allometries conform to global patterns or not, they proved to be sensitive and straightforward descriptors for understanding the macrofauna's response to the deltaic environment.
\end{abstract}

KEY WORDS: Macrofauna $\cdot$ Size spectra $\cdot$ Biomass $\cdot$ Allometry $\cdot$ Respiration $\cdot$ Coastal zone Resale or republication not permitted without written consent of the publisher

\section{INTRODUCTION}

Body size may be used as a unifying tool in the description of the structure of food webs in terrestrial and aquatic ecosystems, owing to its allometric relation to population density, respiration, and other physiological rates, regardless of taxonomic affiliation (Peters 1983). The slope of the density/body size relationship is widely used to predict relative energy use by species of different sizes and constraints in energy flow, especially in terrestrial communities. In these communities, as a rule, this slope is equal to -0.75 and is considered to reflect equal rates of resource utilization by different-sized organisms, assuming that populations grow until limited by competition for resources (Peters \&
Wassenberg 1983). However, no consistent densitybody size relationships have yet emerged for aquatic organisms, merely because size-related patterns of energy use depend on which physiological groups are being compared (Cyr et al. 1997). On the other hand, the use of size spectra, i.e. the distribution of density or biomass over body size classes (Kerr \& Dickie 2001), has revealed patterns related to energy transfer, physical habitat characteristics, and perturbations in aquatic communities (Sheldon et al. 1972, Schwinghamer 1981, Sprules \& Munawar 1986, Strayer 1986).

Spectra with uniform distribution of biomass over the whole size range (i.e. flat shaped) are expected in systems where size class is equivalent to trophic level, and therefore fewer but larger organisms are to be 
expected in successively higher trophic levels (Peters 1983). Deviations from uniformity are thus interpretable in the context of irregularities in the flow of energy from small to large organisms (Sprules \& Munawar 1986). Benthic biomass size spectra (BSS) constructed taking into account all forms of benthic life from bacteria to macrofauna are usually trimodal (Schwinghamer 1981). This deviation from uniformity has been attributed by Strayer (1986) to the lack of direct matching between trophic level and size class, since benthic organisms belonging to different size classes may feed on the same food resource, e.g. the deposit-feeding microfauna, meiofauna, and macrofauna. According to Schwinghamer (1981) the troughs separating microbes (attached to particles), meiofauna (interstitial dwellers), and macrofauna (living on the sediment or burrowing in it) represent discontinuities in the way benthic organisms use the sediment habitat, although experimental testing of this hypothesis gave conflicting results (Duplisea \& Drgas 1999, Duplisea 2000, Leaper et al. 2001). However, Warwick (1993), based on the consistent position of troughs across the metazoan size spectra, suggested that shifts caused by perturbations would be recognizable symptoms of community stress and thus that size spectra would be a useful ataxonomic and amenable to automation, monitoring tools.

Spectra constructed taking into account macrofauna only (i.e. size range: $0.1 \mathrm{mg}$ to $4 \mathrm{~g}$; Duplisea 2000), usually deviate from uniformity. In freshwater habitats, the shapes of macrofaunal size spectra have been found to be uniform (Cattaneo 1993), unimodal (Strayer 1986), bimodal (Hanson et al. 1989), and jagged (Ramsay et al. 1997). On the other hand, marine macrofaunal spectra show a trend of increasing biomass with increasing body size in coastal areas (Schwinghamer 1981, Gerlach et al. 1985). Studies on macrofaunal BSS patterns from marine and freshwater habitats have so far focused on the effect of bathymetric-trophic gradients (Saiz-Salinas \& Ramos 1999), substrate characteristics (Hanson 1990, Rasmussen 1993, Drgas et al. 1998, Duplisea 2000), anthropogenic disturbance such as organic pollution (Gonzalez-Oreja \& Saiz-Salinas 1999, Pagola-Carte 2004) and trawling (Duplisea et al. 2002), and several types of ecological conditions in marine and freshwater habitats (Quiroga et al. 2005). No consistent patterns in the shape of macrofaunal BSS with habitat type have yet emerged, thus encouraging their study in a variety of habitats and ecological conditions.

No macrofaunal BSS are available from subtidal deltaic communities. However, studies have shown that periodic erosional depositional events, fluid muds, and unstable seabeds off the mouth of large rivers significantly reduce numbers, diversity, and sizes of ben- thic macrofauna (Rhoads et al. 1985, Aller \& Stupakoff 1996). Macrobenthic communities in the coastal areas influenced by smaller rivers are impacted in similar ways, although the physical environment is less detrimental than off the mouth of tropical rivers (Moodley et al. 1998, Wijsman et al. 1999). For example, sedimentation rates off the mouth of smaller rivers, such as those draining alpine Europe, are about 30 to 200 times lower than those reported from the world's major rivers (Poulos et al. 1996). However, equally high or higher annual sediment yields than those from the larger rivers of the world have been reported, usually reaching a peak within a few days following heavy rainfall during the autumn and winter months and sudden snow melt during early spring (Milliman 2001).

There is growing evidence that changes in land use in the catchments of small rivers (i.e. deforestation, intensive agriculture, and urbanization) increase sediment yield and deposition with detrimental consequences on the biodiversity, function, and ecological value of estuarine and coastal habitats (GESAMP 1994). The aim of the present study was to analyze the dynamics of density, biomass, and respiration size spectra, as well as the relationships between density and respiration rates and body size of the macrofaunal assemblages along a delta front in the eastern Mediterranean (Maliakos Gulf, Aegean Sea). This allowed us to assess whether such a system is constrained by perturbations or energy supply. In addition, it enabled us to evaluate whether body size is useful as a tool in monitoring studies.

\section{MATERIALS AND METHODS}

The study took place in the inner Gulf of Maliakos (maximum depth: $25 \mathrm{~m}$ ), which receives discharge from the Spercheios River (Fig. 1). The location constitutes a special area of conservation, where trawling is not allowed. The mean annual freshwater discharge rate from the mouth of the Spercheios River is $68 \mathrm{~m}^{3}$ $\mathrm{s}^{-1}$, and approximately $805 \mathrm{t} \mathrm{km}^{-2}$ of sediment is annually exported, forming a 'birdfoot' delta (Poulos et al. 1996). Riverine flow displays maxima during winter and early spring months, coinciding with maxima in concentrations of nutrients, planktonic biomass, and suspended material throughout the inner Gulf of Maliakos (Christou et al. 1995, Kormas et al. 1998, 2003). By contrast, low turbidity as well as nutrient and plankton concentrations occur off the river mouth during minima of riverine flow in summer months.

Sampling took place in May, August, and November 2000 and in February and May 2001. Four stations were selected along a gradient of increasing water transparency and depth from the river mouth (S1) 


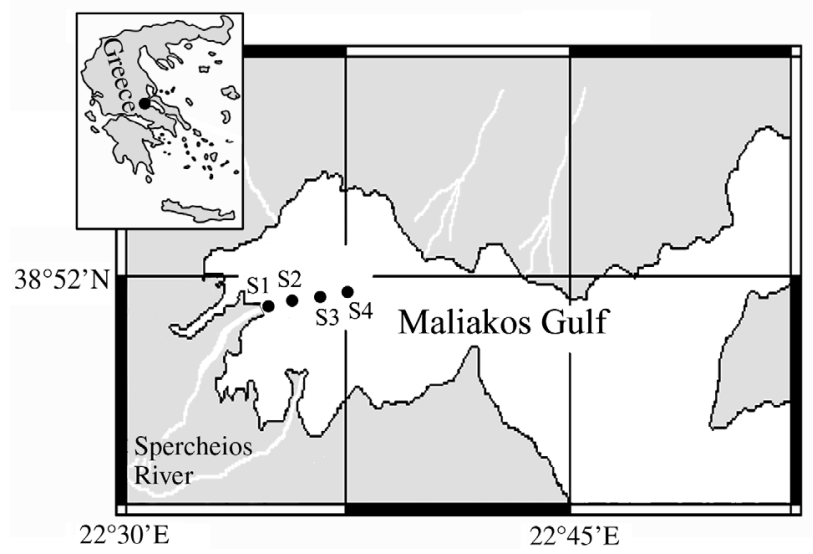

Fig. 1. Map of the inner Gulf of Maliakos, Aegean Sea, Greece, indicating the location of sampling stations

towards the plume area (S4) (Fig. 1, Table 1). Triplicate quantitative benthic samples were taken by means of a Ponar grab (sampling area: $0.05 \mathrm{~m}^{2}$; penetration depth: $15 \mathrm{~cm}$ ). Samples were washed through a sieve with a mesh size of $0.5 \mathrm{~mm}$ to remove sediments, and the organisms retained were fixed in $4 \%$ formaldehyde. Then, the organisms were sieved sequentially through a series of steel test sieves with meshes of 2, 1.5, 1, 0.71, and $0.5 \mathrm{~mm}$, according to Ramsay et al. (1997), applying appropriate modifications. Firstly, in order to account more accurately for large macrofauna, 2 additional steel meshes (8 and $4 \mathrm{~mm}$ ) were added. Secondly, in order to diminish errors introduced by the animal's shape, macrofauna were sorted according to major taxon (Polychaeta, Crustacea, Echinodermata, Mollusca, and Miscellanea) prior to sequential sieving. Following the sieving procedure, organisms were treated with diluted $\mathrm{HCl}$ solution to remove calcareous parts and wet weight biomass (WW) from each taxon retained on each sieve was then weighed to the nearest $0.1 \mathrm{mg}$ after blotting dry on filter paper. Numbers of individuals from each sieve were measured, and large and conspicuous specimens from all major taxa were identified to species level.

Individual body wet weight (WWi) per grab sample per major taxon was calculated by dividing the WW of each taxon from each sieve by the corresponding number of individuals. Subsequently, data from the 3 replicates per sampling station were pooled and converted to square meters. The size spectrum at each station was constructed by plotting the total density and biomass in each size class across taxa for each sampling time (Hanson 1990) against the biomass data divided in $15 \log _{2}$-based size classes ( 0 to $0.25,0.25$ to $0.5,0.5$ to $1, \ldots, 1024$ to 2048,2048 to $4096 \mathrm{mg}$ ). For practical reasons, the 1 st to 5 th size classes (up to $\log _{2} \mathrm{WWi}=2$ mg) will hereafter be referred to as the small size classes; the 6th to 10th (up to $\log _{2} \mathrm{WWi}=7 \mathrm{mg}$ ), as the intermediate size classes; and the 11th to the 15th (up to $\log _{2} \mathrm{WWi}=12 \mathrm{mg}$ ), as the large size classes. The normalized biomass size spectra (NSS) were determined by regressing the $\log _{2}$ [(seasonal mean biomass in size class) / (weight range of the interval)] against the $\log _{2}$ of the upper limit of the size class, following Sprules \& Munawar (1986) and Hanson (1990). The slopes of these regression lines can then be used to characterize biomass trends across the size spectrum and to compare the size structure among communities.

Individual respiration rates (Ri: oxygen consumption in $\mu \mathrm{l} \mathrm{h}^{-1}$ ) were estimated from mean individual body mass (WWi) of each size class and taxon, according to the equation by Banse (1982, his Table 1, poikilotherms at $20^{\circ} \mathrm{C}$ ): $\log _{10} \mathrm{Ri}=1.29+0.74 \log _{10} \mathrm{Wi}$, where Wi (in $\mathrm{mg}$ ) is the ash-free dry weight estimated from WWi using standard conversion factors for each taxon (Ricciardi \& Bourget 1998). Population respiration rates were calculated for each taxon and size class as the product of measured population density and predicted Ri, as suggested by Cyr et al. (1997). The respiration size spectra were constructed plotting the total respiration rate $\left(\mathrm{mmol} \mathrm{m}^{-2} \mathrm{~d}^{-1}\right)$ in each size class for each sampling time. Mean density and respiration from each taxon and size class were plotted against mean body size per size class at each station.

The slopes of all regressions were compared by ANCOVA (F-tests, Zar 1984). Differences in the biomass size spectra among the 4 stations were tested with non-parametric multivariate analysis of variance (npMANOVA, 9999 permutations; Anderson 2001), applying the Bray-Curtis distance measure and using

Table 1. Water column and sediment characteristics at the 4 stations in the inner Gulf of Maliakos during the course of the study (May 2000 to May 2001)

\begin{tabular}{|lcccccc|}
\hline Stations & $\begin{array}{c}\text { Depth } \\
(\mathrm{m})\end{array}$ & $\begin{array}{c}\text { Distance from } \\
\text { river mouth }(\mathrm{km})\end{array}$ & $\begin{array}{c}\text { Salinity } \\
(\%)\end{array}$ & $\begin{array}{c}\text { Temperature } \\
\left({ }^{\circ} \mathrm{C}\right)\end{array}$ & $\begin{array}{c}\text { Secchi disk } \\
\text { depth }(\mathrm{m})\end{array}$ & $\begin{array}{c}\text { Median grain } \\
\text { size }(\mu \mathrm{m})\end{array}$ \\
\hline S1 & 4.0 & 0.2 & $14.5-35.0$ & $12.5-25.8$ & $0.5-2.2$ & $4-28$ \\
S2 & 7.5 & 1.0 & $36.1-36.9$ & $13.0-25.0$ & $1.8-3.0$ & $6-15$ \\
S3 & 12.5 & 1.8 & $36.4-37.1$ & $13.8-24.0$ & $2.7-3.4$ & $6-15$ \\
S4 & 22.0 & 3.0 & $36.7-37.5$ & $13.8-24.0$ & $4.5-13.2$ & $6-12$ \\
\hline
\end{tabular}


the samples from different sampling times as replicate units at each station. Nested 2-way ANOVA was used to test for significant differences in density and biomass from the 3 replicate samples among stations and sampling times within each station. In case the nested factor was significant, 1-way ANOVA was performed to test for significant temporal differences within each station separately, followed by a posteriori StudentNewman-Keuls (SNK) comparisons. To satisfy the assumption of homogeneity of variance (Cochran's $C$ test, $\mathrm{p}>$ 0.05), data were log transformed prior to analysis.

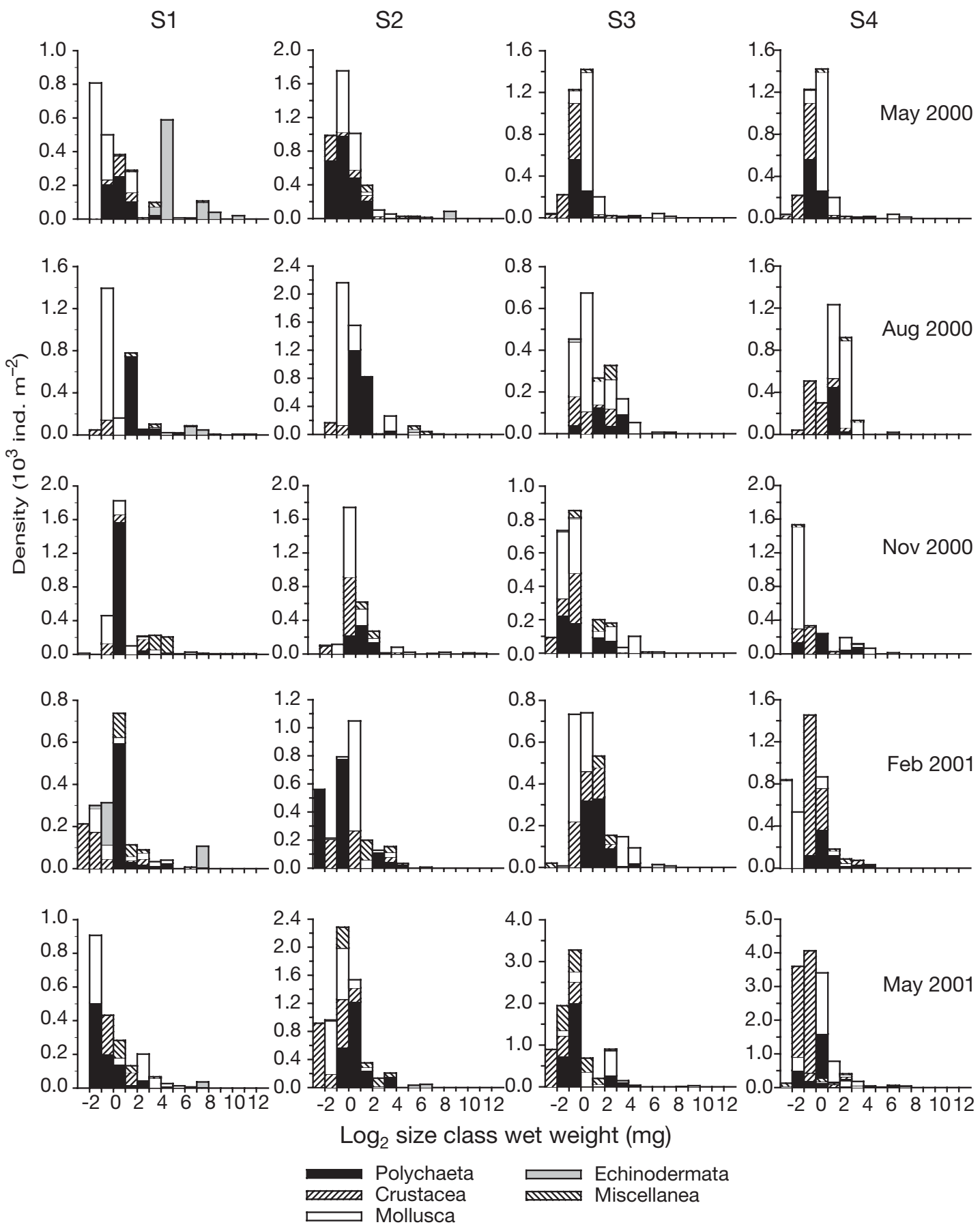

Fig. 2. Seasonal variation of density size spectra of the macrofaunal community at the 4 stations in the inner Gulf of Maliakos. The contributions of major taxa identified (Polychaeta, Crustacea, Mollusca, Echinodermata, Miscellanea) are shown. Note the differences in scale 


\section{RESULTS}

Average population density ranged from $2040 \pm 575$ ind. $\mathrm{m}^{-2}$ (S3, August 2000) to $10746 \pm 341$ ind. $\mathrm{m}^{-2}$ (S4, May 2001). Although no differences were found among stations $\left(F_{3,16}=1.32, \mathrm{p}>0.05\right)$, temporal variation within each station was significant $\left(F_{16,40}=6.11\right.$, $\mathrm{p}<0.001)$. Significantly lower densities were found at S1 in February and May $2001\left(F_{4,10}=12.54, \mathrm{p}<0.001\right)$, at S2 in November 2000 and February $2001\left(F_{4,10}=\right.$ $4.19, \mathrm{p}<0.05)$, at S3 in August and November 2000 and in February $2001\left(F_{4,10}=25.72, \mathrm{p}<0.0001\right)$. By contrast, at S4 significantly lower density was detected at all times, except for May $2001\left(F_{4,10}=5.90, \mathrm{p}<0.05\right)$.

A wide range of density size spectra was encountered in this study (Fig. 2). The position of density modal classes varied among stations and sampling times. However, the highest values were always displayed by individuals $<4 \mathrm{mg}$ WWi. Individuals $<0.25 \mathrm{mg}$ (first size class), mainly comprising mollusks, polychaetes, amphipods, and decapod larvae, were found at S1 only in February 2001, while these were present more frequently and at higher numbers at S2 (February and May 2001), S3, and S4 (all sampling times except for August 2000). The contribution of major taxa to total density per size class was also variable. At Station S1, small mollusks, especially gastropods, dominated total density in May and August 2000, while small polychaetes and crustaceans dominated density in November 2000 and February and May 2001. Echinoids (i.e. exclusively the species Echinocardium cordatum) from the intermediate size classes, highly contributed to total density at S1 in May 2000. Mollusks, polychaetes, and crustaceans from small size classes prevailed over other taxa and size classes at S2, S3, and S4 at all sampling times.

The plots of overall density against body size did not differ significantly among stations $\left(F_{3,394}=1.35, \mathrm{p}>0.05\right)$ (Fig. 3) and were slightly negative $\left(b_{\text {common }}=-0.39 \pm\right.$ $\left.0.03 \mathrm{SE}, F_{1,400}=189.6, \mathrm{p}<0.001\right)$. Examination of the slopes at each station and sampling time separately yielded similar results. Despite the decrease of the upper boundary of density with increasing body size, the presence of many taxa represented by only 1 individual across the whole size spectrum at all stations and sampling times resulted in a flat lower boundary, thus precluding a strongly negative regression.
Average biomass ranged from $4.2 \pm 0.4 \mathrm{~g} \mathrm{~m}^{-2}$ (S4, February 2001) to $81.7 \pm 7.5 \mathrm{~g} \mathrm{~m}^{-2}$ (S1, May 2000). No significant differences were found among stations $\left(F_{3}\right.$, $\left.{ }_{16}=2.92, \mathrm{p}>0.05\right)$. However, significant temporal variation was observed within each station $\left(F_{16,40}=3.63\right.$, $\mathrm{p}<0.001)$. Significantly lower biomass levels were detected at S1 in November 2000, and in February and May $2001\left(F_{4,10}=10.92, \mathrm{p}<0.01\right)$, and at S2 in February and May $2001\left(F_{4,10}=4.43, \mathrm{p}<0.05\right)$. No significant temporal differences were found at $\mathrm{S} 3\left(F_{4,10}=1.18, \mathrm{p}>\right.$ 0.05), while at $\mathrm{S} 4$ significantly higher biomass was observed in May $2001\left(F_{4,10}=3.94, \mathrm{p}<0.05\right)$.

Biomass size spectra varied among stations in their position and taxonomic composition of modal classes, and the biomass partitioned in each size class (Fig. 4). However, no significant differences among stations were detected (npMANOVA, $F_{3,16}=1.38, \mathrm{p}>0.05$ ). The occurrence of echinoderm species, i.e. Echinocardium cordatum, dominating at S1, Amphiura chiajei, most abundant at S2, and Asterina sp., found at S3 and $\mathrm{S} 4$, in the large size classes is a noteworthy feature

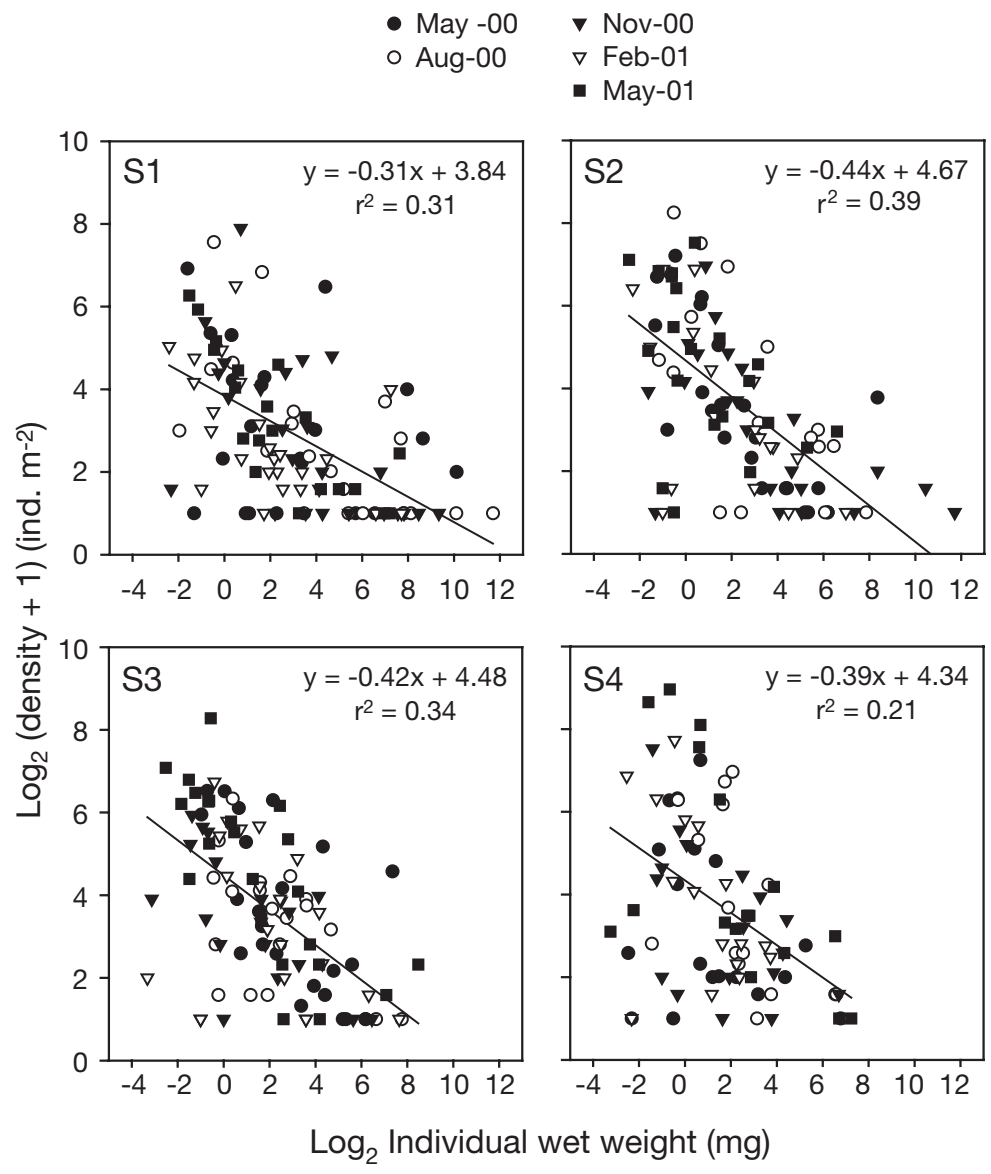

Fig. 3. Overall density/body size relationship plots at the 4 stations in the inner Gulf of Maliakos. Density and body size represent mean number of individuals $\left(\log _{2}[\mathrm{x}+1]\right.$ transformed) and mean individual wet weight $\left(\log _{2}[\mathrm{x}]\right.$ transformed), respectively, for each major taxon identified in each size class 
of the present data set. Spectra were jagged at Stations S1 and S2, with variable taxonomic composition of modal classes and an overall increase of biomass with body size. At S3, the spectra were bimodal or trimodal, while, at S4, the spectra were usually bimodal. Biomass in the large size class consistently comprised $45 \%$ of the total biomass at Station S1. By contrast, the contribution of biomass of the large size classes to the total biomass varied from 0 to $99 \%$ at $\mathrm{S} 2$, from 0 to $64 \%$ at S3, and from 0 to $6 \%$ at S4.

Troughs in the biomass size spectra were usually found after the 8th size class at Stations S3 and S4 and at all stations in February (Fig. 4). These troughs were usually followed by the presence of a single or a very

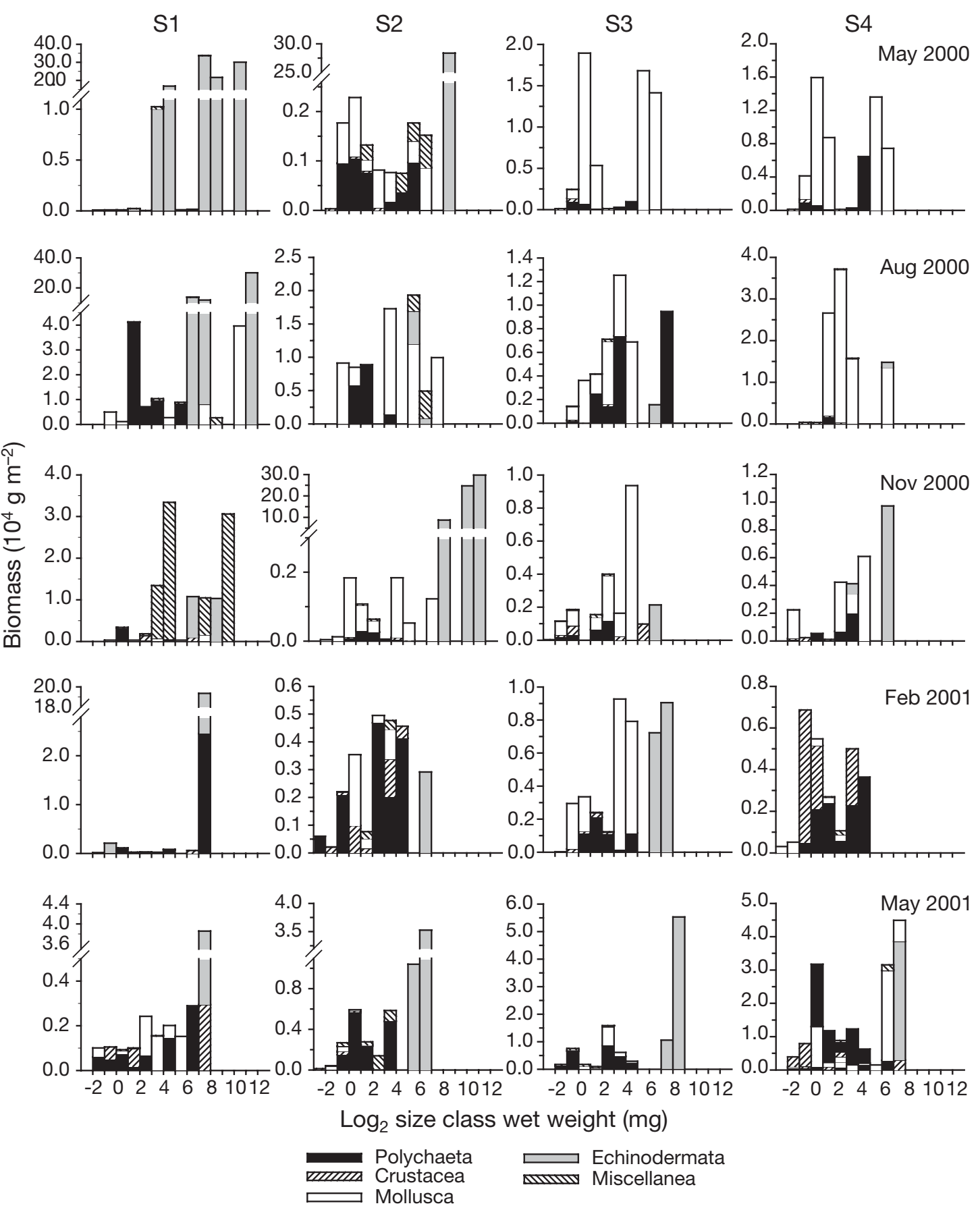

Fig. 4. Seasonal variation of biomass size spectra of the macrofaunal community at the 4 stations in the inner Gulf of Maliakos. The contributions of major taxa identified (Polychaeta, Crustacea, Mollusca, Echinodermata, Miscellanea) are shown. Note the differences in scale and scale breaks 


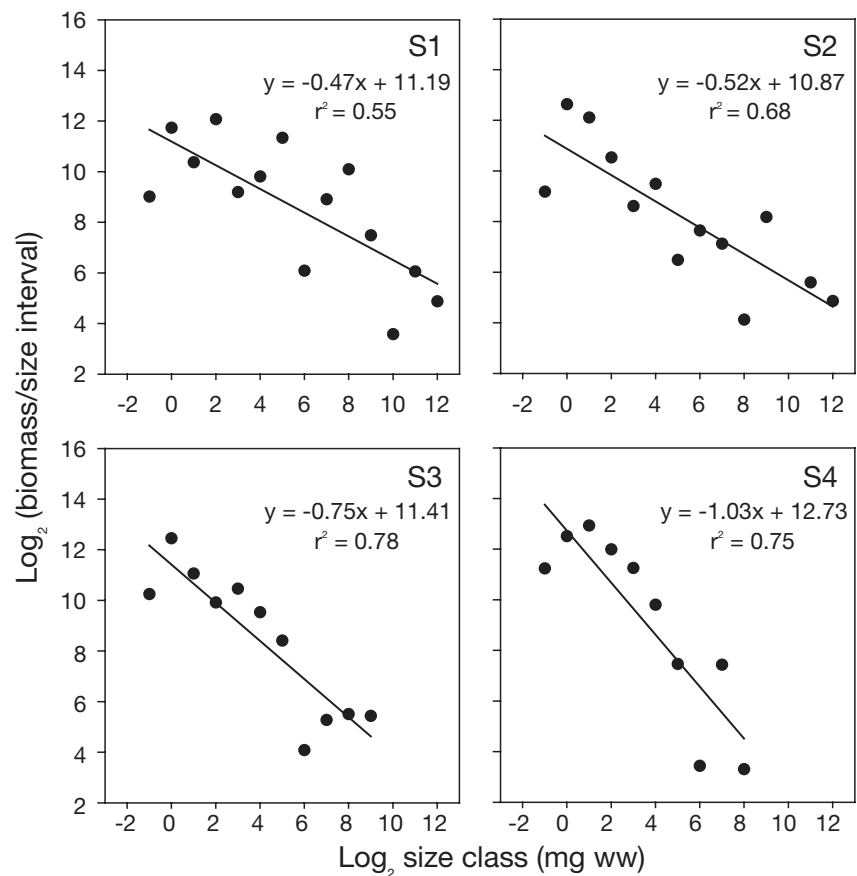

Fig. 5. Seasonally averaged normalized biomass size spectra for the macrofaunal community at the 4 stations of the inner Gulf of Maliakos

few large individuals in the next size class belonging to polychaetes, echinoderms, and mollusks. On the other hand, at Stations S1 and S2, any troughs positioned at the right end of the size range mainly separated the large individuals of the species Echinocardium cordatum and Amphiura chiajei from the other taxa of the community.

Normalized biomass size spectra were computed after pooling the weight from the 1 st and 2nd biomass size class, because the $1 \mathrm{st}$ size class (from 0 to $0.25 \mathrm{mg}$ WWi) contained no biomass in many cases. These spectra were significant at all stations $(\mathrm{p}<0.002)$, with the residual variations being smaller at the deeper $\left(\mathrm{r}^{2}=\right.$ 0.75 to 0.78$)$ than at the shallower stations $\left(r^{2}=0.56\right.$ to 0.68) (Fig. 5). The slopes of the normalized size spectra were significantly different among stations (ANCOVA: $\left.F_{3,40}=6.05, \mathrm{p}<0.025\right)$ and became steeper from the river mouth $(-0.47)$ towards the plume area $(-1.03)$. Less negative slopes were associated with the accumulation of total biomass to larger sized organisms (as at $\mathrm{S} 1$ and S2), while the slope close to -1 at S4 was associated with high contribution of both the small and intermediate size classes to total biomass.

Respiration size spectra showed an increase of respiration rates with body size in many cases, especially near the river mouth (S1 and S2) (Fig. 6). Total macrofaunal respiration rates, calculated as the sum of respiration rates of all size classes at each station, ranged from $0.9 \mathrm{mmol} \mathrm{m}^{-2} \mathrm{~d}^{-1}$ (S4, May 2000) to $33.2 \mathrm{mmol} \mathrm{m}^{-2}$ $\mathrm{d}^{-1}$ (S1, May 2000). At the river mouth (S1), large size classes accounted for 25 to $89 \%$ of total respiration (Fig. 7). By contrast, at the plume area (S4), small size classes accounted for 28 to $76 \%$ of total respiration, while the large individuals only slightly contributed $(2.4 \%)$ to macrofaunal oxygen consumption in May 2001 (Fig. 7). No consistent trend in respiration rates was observed at Stations S2 and S3 (Fig. 7).

The relationships between macrofaunal respiration rates $(\mathrm{R})$ and body size significantly differed among stations $\left(F_{3,394}=6.9, \mathrm{p}<0.001\right)$ (Fig. 8). The slopes of the regression lines were slightly positive at S2 $(b=$ $\left.0.24 \pm 0.06 \mathrm{SE}, F_{1,99}=36.5, \mathrm{p}<0.05\right), \mathrm{S} 3(b=0.28 \pm 0.06$ $\left.\mathrm{SE}, F_{1,104}=16.9, \mathrm{p}<0.001\right)$, and $\mathrm{S} 4(b=0.30 \pm 0.09 \mathrm{SE}$, $\left.F_{1,81}=10.3, \mathrm{p}<0.05\right)$. At these stations the lower boundary of metabolism linearly increased with body size, while the upper boundary only slightly decreased with body size, thus precluding an overall stronger regression. By contrast, at $\mathrm{S} 1$, the regression was very positive $\left(b=0.59 \pm 0.06, F_{1,110}=94.1, \mathrm{p}<0.001\right)$. At this station, decomposing the overall regression into seasons revealed significant agreement with a slope of 0.75 in November $2000\left(b_{\mathrm{N}}=0.63 \pm 0.15, F_{1,22}=16.7\right.$, $\mathrm{p}<0.001)$ and February $2001\left(b_{\mathrm{F}}=0.73 \pm 0.14, F_{1,23}=\right.$ $27.3, \mathrm{p}<0.001)$.

\section{DISCUSSION}

Body size distributions of population density, biomass, and respiration exhibited considerable variation along the delta front of the Gulf of Maliakos. The influence of riverine discharges is more prominent from late winter to spring, as evidenced by the significant decrease in density, biomass, and maximum body size in the winter months and/or in May 2001, especially near the river mouth. Apart from this trend, the size spectra of the macrofauna were intra-annually inconsistent in terms of taxonomic composition and position of modal classes. As a result, this variation confounded the detection of statistically significant differences among stations. With the exception of a few studies from stream communities that provided strong evidence of intra-annual variations in BSS (Stead et al. 2005 and literature cited therein), temporal variations have either been low (for instance Rodriguez \& Magnan 1993) or not been taken into account in sampling designs. Therefore, there is little or no evidence whether or not patterns described for marine habitats are temporally persistent. Nevertheless, the temporal variation in density and biomass size spectra revealed in the Gulf of Maliakos suggests that no single factor, such as riverine fluxes, determines the distribution of macrofaunal body size in a delta front community at all times. As shown in Table 2, the use of seasonally aver- 
aged NSS, as well as density- and respiration-body size allometries in combination with the information derived from density and biomass size spectra, allowed us to relate macrofaunal community size structure with the special, spatial and temporal, features of the deltaic environment. This enabled us to consider the constraints imposed on the deltaic benthos, in terms of resource supply and perturbations.

The present data set demonstrated the dominance of large individuals in terms of biomass at all stations except for S4 in the plume area. The use of NSS based on annual averages enabled the detection of a gradual change in the distribution of biomass across the macrofaunal size spectrum in parallel to gradients from the river mouth to the plume area (Table 2). Based on size spectra from plankton communities, Sprules \& Munawar (1986) suggest that high residual variation in the NSS, as observed near the river mouth in the Gulf of Maliakos, signifies perturbations in the energy flow. Higher variation near the river mouth agrees with the

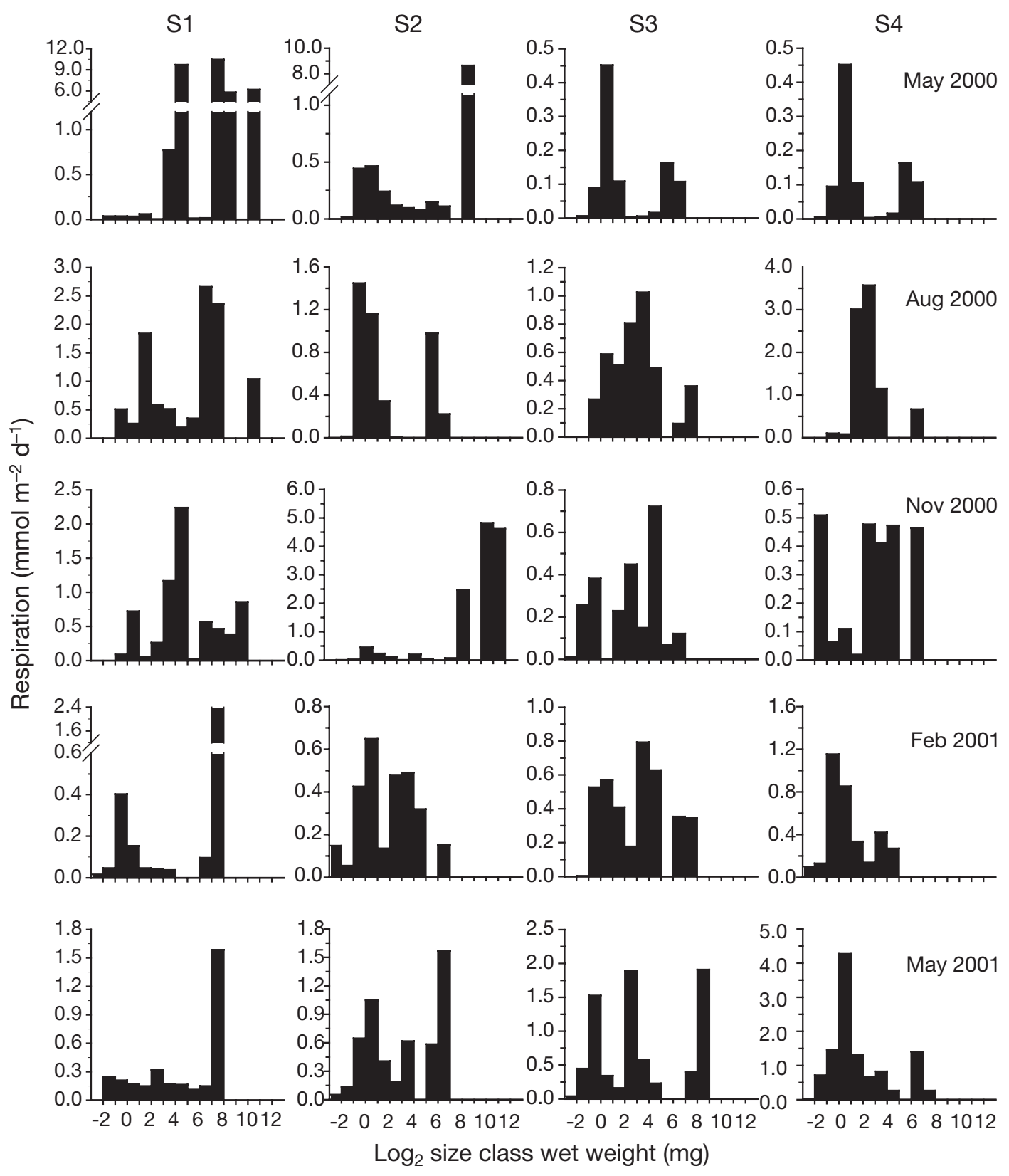

Fig. 6. Seasonal variation of respiration size spectra of the macrofaunal community at the 4 stations in the inner Gulf of Maliakos. Respiration rates were estimated from body size using empirical equations (Banse 1982) and converted to $\mathrm{mmol}_{2} \mathrm{~m}^{-2} \mathrm{~d}^{-1}$. Note the differences in scale and scale breaks 


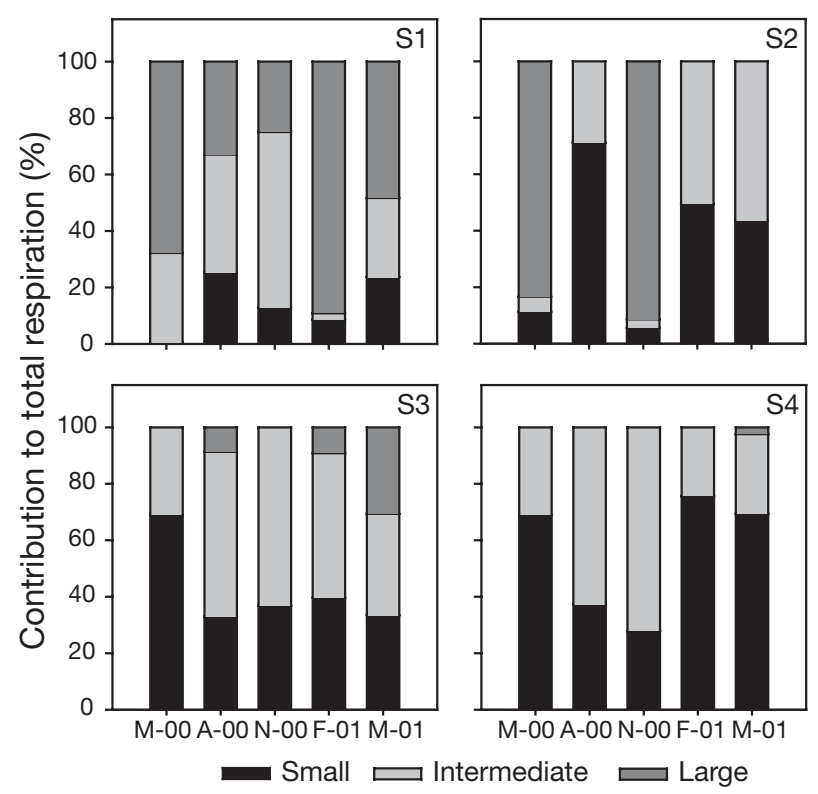

Fig. 7. Seasonal variation of the contribution (\%) of major size groups to total respiration at the 4 stations in the inner Gulf of Maliakos. Total respiration was calculated as the sum of respiration rates of each size class, at each station and sampling time (small: 1 st to 5 th size class; intermediate: 6 th to 10 th size class; large: 11th to 15th size class). Date abbreviations as in Figs. $3 \& 8$

highly dynamic and variable ecological conditions in deltaic environments (Aller \& Stupakoff 1996). In benthic communities, an NSS slope less negative than -1 is considered to correspond to high productivity, allowing the presence of large individuals, usually filter feeders, at elevated densities (Rodriguez \& Magnan 1993, Drgas et al. 1998, Saiz-Salinas \& Ramos 1999). In this context, our NSS slopes indicated higher food inputs closer to the river mouth than in the plume area. However, sedimentary organic matter is highly labile throughout the inner Gulf of Maliakos (Akoumianaki 2004, Akoumianaki \& Nicolaidou 2004). Moreover, the increased chl a inputs during late winter to early spring (Christou et al. 1995) coincided with an increase in the densities of very small, most likely recruiting individuals, and intermediate sized suspension feeders, such as amphipods and phoronids, at all stations and not with high numbers of large suspension-feeding individuals as expected. In addition, the large individuals comprised mostly deposit feeders and predators, while suspension feeders were represented by a few large specimens of Amphiura chiajei. Therefore, the role of food quality gradients must be negligible in causing the gradual changes observed in macrofaunal NSS. These results are in agreement with the finding of Rasmussen (1993) that perturbations (wave exposure in his study) rather than increased trophic status favor the prominence of the large over small size classes in the benthic BSS.

The slope of the NSS was more negative at the stations where the biomass and density of large individuals decreased. Large burrowing deposit- and suspension-feeding species (Echinocardium cordatum and Amphiura chiajei, respectively) prevailed near the river mouth (Stations S1 and S2, respectively), as dwelling deeper in the sediment enables them to withstand fluctuations in sedimentation regime and sediment instability (Rhoads et al. 1985, Aller \& Stupakoff 1996). On the other hand, the large size classes at the margins of the delta front (at S3 and S4) comprised predatory taxa, such as nemerteans and polychaetes (i.e. Nepthys sp., Glycera sp.), that reached lower maximum body size than the large individuals at S1 and S2. These results provided indirect evidence that natural disturbance rather than productivity determined the shape and the taxonomic composition of the bio-

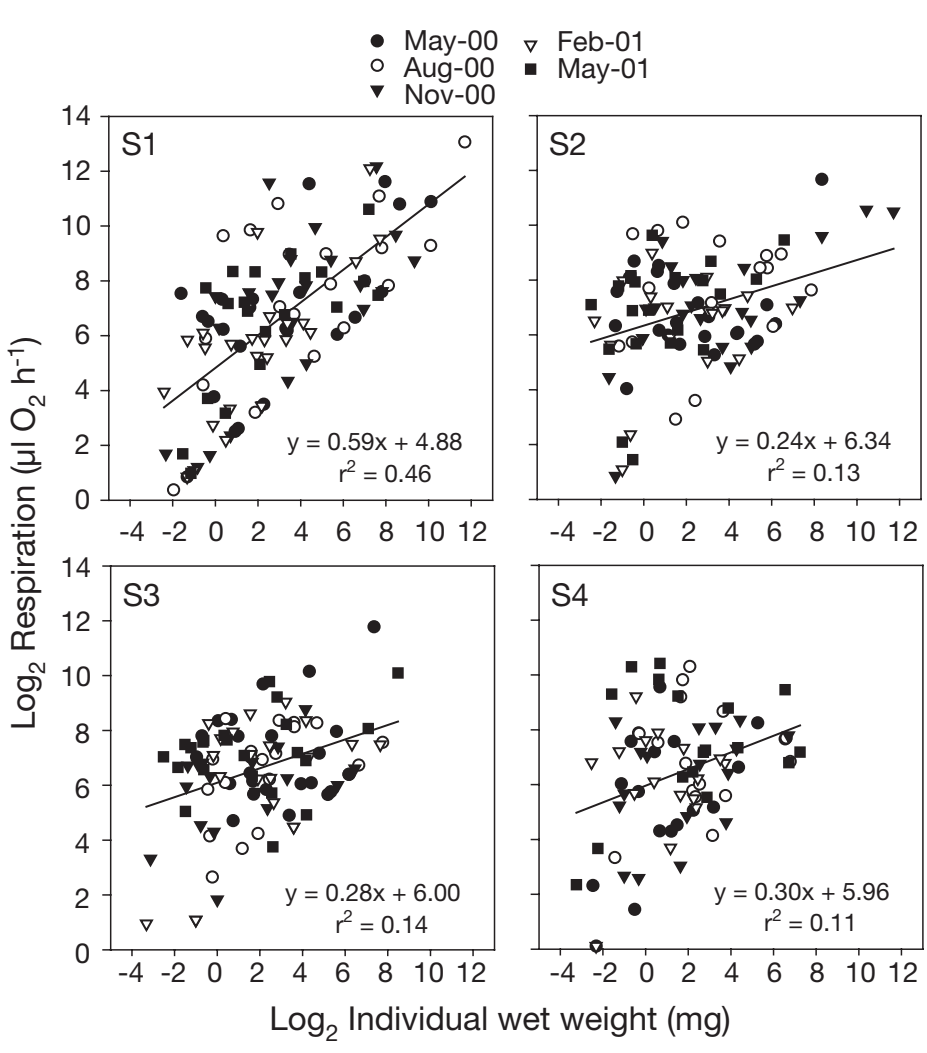

Fig. 8. Overall respiration-body size relationship plots at the 4 stations in the inner Bay of Maliakos. Respiration values represent mean respiration $\left(\mathrm{Hl} \mathrm{O}_{2} \mathrm{~h}^{-1}\right)$ of different taxa and mean individual body size (mg) at each sampling time. Respiration rates were estimated from body size using empirical equations (Banse 1982) 
Table 2. Macrofaunal size structure along the deltaic depositions of the inner Gulf of Maliakos and possible energy use constraints imposed on the macrofaunal community by the deltaic environment. Density size structure was assessed using density size spectra at each sampling time as well as overall density/body size relationships. Biomass size structure was evaluated using biomass size spectra at each sampling time and the slopes of seasonally averaged normalized biomass size spectra (NSS). Metabolic size structure was estimated by means of overall and seasonal respiration-body size allometries (OM: organic material $b_{\mathrm{NSS}}$ : slope of normalized biomass size spectra; $b_{\mathrm{D}}$ : slope of density/body size relationship; $b_{\mathrm{R}}$ : slope of respiration-body size relationship; D: density; R: respiration rate). ${ }^{*}$ Data sources: Christou et al. (1995), Poulos et al. (1996), Akoumianaki (2004), and present study

\begin{tabular}{|c|c|c|c|}
\hline & River mouth & Between mouth and plume area & Plume area \\
\hline $\begin{array}{l}\text { Delta } \\
\text { characteristics }{ }^{*}\end{array}$ & $\begin{array}{l}\text { High sedimentation and phyto- } \\
\text { detrital inputs with maxima in } \\
\text { winter, high turbidity, variable } \\
\text { salinity and grain size, sediment } \\
\text { instability (i.e. hydrodynamic } \\
\text { forcing), consistently labile } \\
\text { sedimentary OM }\end{array}$ & $\begin{array}{l}\text { Maximum phytodetrital inputs in } \\
\text { winter and spring, high turbidity, } \\
\text { variable grain size, sediment } \\
\text { instability (i.e. hydrodynamic } \\
\text { forcing), consistently labile } \\
\text { sedimentary OM }\end{array}$ & $\begin{array}{l}\text { Variable phytodetrital inputs } \\
\text { and turbidity, sediment } \\
\text { instability (i.e. hydrodynamic } \\
\text { forcing), consistently labile } \\
\text { sedimentary OM }\end{array}$ \\
\hline $\begin{array}{l}\text { Density size } \\
\text { structure }\end{array}$ & $\begin{array}{l}\text { Highest D in small size classes. } \\
\text { Considerable contribution of large } \\
\text { and intermediate sized individuals } \\
\text { to total D. Sporadic occurrence of } \\
\text { very small individuals. Wide } \\
\text { size range of single specimens. } \\
b_{\mathrm{D}}=-0.31\end{array}$ & $\begin{array}{l}\text { Highest D in small size classes. } \\
\text { Low contribution of large indi- } \\
\text { viduals to total D. Considerable } \\
\text { numbers of very small indivi- } \\
\text { duals. Wide size range of single } \\
\text { specimens. } \\
-0.44<b_{\mathrm{D}}<-0.42\end{array}$ & $\begin{array}{l}\text { Highest D in small size classes. } \\
\text { Very low contribution of large } \\
\text { individuals to total D. Wide } \\
\text { range of densities of very small } \\
\text { individuals. Wide size range } \\
\text { of single specimens. } \\
b_{\mathrm{D}}=-0.39\end{array}$ \\
\hline $\begin{array}{l}\text { Biomass size } \\
\text { structure }\end{array}$ & $\begin{array}{l}\text { Accumulation of biomass in } \\
\text { large burrowing individuals. } \\
-0.52<b_{\mathrm{NSS}}<-0.47\end{array}$ & $\begin{array}{l}\text { Accumulation of biomass in } \\
\text { intermediate sized and large } \\
\text { predatory individuals. } \\
b_{\mathrm{NSS}}=-0.75\end{array}$ & $\begin{array}{l}\text { Accumulation of biomass in } \\
\text { small and intermediate size } \\
\text { classes. } \\
b_{\text {NSS }}=-1.03\end{array}$ \\
\hline $\begin{array}{l}\text { Metabolic size } \\
\text { structure }\end{array}$ & $\begin{array}{l}\text { Winter: } \mathrm{R} \text { increases with increa- } \\
\text { sing body size. Decrease of } \mathrm{D} \\
\text { and biomass in all size classes. } \\
0.63<b_{\mathrm{R}}<0.73 \\
\text { Spring/summer: maxima R in } \\
\text { large and intermediate size } \\
\text { classes. Increase of D and bio- } \\
\text { mass in all size classes. } \\
0.50<b_{\mathrm{R}}<0.59\end{array}$ & $\begin{array}{l}\text { Overall: maxima } \mathrm{R} \text { in large size } \\
\text { classes. Wide range of } \mathrm{R} \text { across } \\
\text { small and intermediate size classes. } \\
0.10<b_{\mathrm{R}}<0.37\end{array}$ & $\begin{array}{l}\text { Overall: maxima } \mathrm{R} \text { in small } \\
\text { size classes. High variety of } \mathrm{R} \\
\text { in small size classes. } \\
0.10<b_{\mathrm{R}}<0.49\end{array}$ \\
\hline $\begin{array}{l}\text { Energy use } \\
\text { constraints }\end{array}$ & $\begin{array}{l}\text { Overall: sedimentation and } \\
\text { hydrodynamics suppress the } \\
\text { numbers of small individuals. } \\
\text { Winter: burial risk for all indi- } \\
\text { viduals, independent of body size }\end{array}$ & $\begin{array}{l}\text { Overall: hydrodynamics limit } \\
\text { D of surface living small and } \\
\text { intermediate sized individuals }\end{array}$ & $\begin{array}{l}\text { Overall: hydrodynamics limit } \\
\text { D of surface living small and } \\
\text { intermediate sized individuals }\end{array}$ \\
\hline
\end{tabular}

mass size spectra in the delta front of the Gulf of Maliakos (Table 2).

In the Gulf of Maliakos, the density/body size relationships were either weakly negative or insignificant, thus not supporting the 'energy equivalence rule' according to which a community is resource limited when density scales as the -0.75 power of body size (Peters \& Wassenberg 1983). The shape of these relationships was roughly triangular, because of the wide density range of small individuals ( 0.1 to $4 \mathrm{mg}$ ) and the wide size range of scarce individuals. Stead et al. (2005) suggest that many small and rare taxa are char- acteristic of non-equilibrium communities in changing environments. In particular, the flat lower boundary in the density/body size relationships in the Gulf of Maliakos could be explained by the prevailing environmental conditions. In shallow areas with very fine sedimentary environment, such as the study site, hydrodynamics operating at wide spatial scales can transport sediment and remove surface macrofauna, especially the non-tube-dwelling individuals (Rhoads et al. 1985, Turner et al. 1997), limiting the abundance of surface living, small and intermediate sized individuals. Thus, the flat lower boundary indicated that 
hydrodynamics, by disturbing the surface macrofauna, may constrain the density/body size relationship.

Respiration rates reflect resource uptake rates but also living cost depending on environmental conditions. We estimated oxygen consumption rates from empirical equations based on laboratory measurements in ideal conditions at $20^{\circ} \mathrm{C}$ (Banse 1982). Thus, the resultant respiration spectra do not reflect seasonally driven variations in the metabolic activity of the constituent taxa. In addition, these spectra have not taken into account differences in the motility of active, predatory, surface-living taxa that are more prone to ambient variations and those that are discretely motile and live deeper in the sediment. However, they proved useful in comparing the respiration rates across the macrofaunal size spectrum among stations and sampling times, assuming that individuals are all equally active regardless of maintenance processes. Resource utilization rates in the inner Gulf of Maliakos showed an increase with increasing body size, most prominent at the river mouth, indicating that large individuals can be more successful at the river mouth than in the plume area. By contrast, previous studies from unperturbed coastal (Gerlach et al. 1985) and lacustrine habitats (Strayer 1986), using similar methods for the estimation of respiration rates, demonstrated that no single size class dominates energy flow in the zoobenthos.

With the exception of S1 at the river mouth, the slopes of respiration-body size relationships in the Gulf of Maliakos were slightly positive, similar to those reported by Cyr et al. (1997) for aquatic invertebrates from a variety of lakes. This suggested that the macrofaunal community is not constrained by energy supply along the delta front or in the plume area of the inner Gulf of Maliakos. However, a clearly positive relationship at Station S1, with a slope approximating 0.75 in November and February, i.e. during the period of maximum riverine sediment discharges, indicated that the macrofaunal community was constrained at the river mouth. Bearing in mind that during summer, when the system farther away from the river mouth switches to 'oligotrophy' (Kormas et al. 1998), no respiration-body size regression slopes close to 0.75 were observed at any of the stations, then the perturbations induced by riverine sediment and freshwater discharges offer the most plausible explanation for the highly positive regression slopes in November 2000 and February 2001 at S1 (Table 2).

The results of the present study were based on an exceptionally detailed data set that accounted for spatial as well as temporal variation of macrofaunal body size. Identification of individuals to major taxonomic groups, i.e. from classes to phyla, allowed us to make inferences about their feeding guilds and functional roles, especially for the large individuals. Moreover, body size distributions enabled us to record the dynamics and relationships of important groups of macrofauna, i.e. the recently recruited taxa that were small and not easily identified to species level and the easily identified large individuals. Density and biomass trends of small individuals indicated that colonization is a frequent phenomenon in the Gulf of Maliakos, but that it is suppressed considerably at the river mouth. In addition, the increasing contribution of small individuals to the energy flow with increasing distance from the river mouth suggested that the recently recruited individuals are the most vulnerable part of the community under increased sedimentation. Large individuals also declined during the winter period, indicating that the enhanced riverine discharges may limit their populations. A taxonomically based community structure analysis could not reveal such phenomena. This makes the approach described here especially attractive in monitoring studies, since the interest in coastal areas with considerable land runoff is focused on the effects of sedimentation (GESAMP 1994). In conclusion, macrofaunal body size, regardless of taxonomic affiliation, is a sensitive descriptor of the constraints imposed on macrofaunal community in a deltaic environment. Irrespective of whether size spectra and body size allometries conform to global, if any, patterns or not, they proved to be useful and straightforward tools in understanding this complex system.

Acknowledgements. This research was supported by special funding for doctoral preparation from the University of Crete. We thank Prof. A. Eleftheriou for his helpful comments on an earlier version of the manuscript.

\section{LITERATURE CITED}

Akoumianaki I (2004) Macrobenthic communities of subaqueous deltaic depositions: the case of a semi-enclosed gulf in the eastern Mediterranean (Maliakos Gulf, Greece). PhD dissertation, University of Crete, Heraklio (English abstract)

Akoumianaki I, Nicolaidou A (2004) Sedimentary organic matter lability along the river-shelf transition zone in a semi-enclosed bay (Maliakos Bay, Aegean Sea, Greece). Rapp P-V Reun Comm Explor Sci Int Mer Mediterr Monaco 37:167

Aller JY, Stupakoff I (1996) The distribution and seasonal characteristics of benthic communities on the Amazon shelf as indicators of physical processes. Cont Shelf Res 16 $(5 / 6): 717-751$

Anderson MJ (2001) A new method for non-parametric multivariate analysis of variance. Aust J Ecol 26:32-46

Banse K (1982) Mass scaled rates of respiration and intrinsic growth in various invertebrates. Mar Ecol Prog Ser 9: 281-297

Cattaneo A (1993) Size spectra in benthic communities in 
Laurentian streams. Can J Fish Aquat Sci 50:2659-2666

Christou ED, Pagou K, Christianidis S, Papathanasiou E (1995) Temporal and spatial variability of plankton communities in a shallow embayment of the eastern Mediterranean. In: Eleftheriou A, Ansell AD, Smith CJ (eds) Biology and ecology of shallow coastal waters. Olsen and Olsen, Fredensborg, p 3-10

Cyr H, Peters RH, Downing JA (1997) Population density and community size structure: comparison of aquatic and terrestrial systems. Oikos 80:139-149

Drgas A, Radziejewska T, Warzocha J (1998) Biomass size spectra of near-shore shallow-water benthic communities in the Gulf of Gdansk (southern Baltic Sea). PSZNI Mar Ecol 19(3):209-228

Duplisea DE (2000) Benthic organism biomass size-spectra in the Baltic Sea in relation to the sediment environment. Limnol Oceanogr 45(3):558-568

Duplisea DE, Drgas A (1999) Sensitivity of a benthic, metazoan, biomass size spectrum to differences in sediment granulometry. Mar Ecol Prog Ser 177:73-81

Duplisea DE, Jennings S, Warr KJ, Dinmore TA (2002) A sizebased model of the impacts of bottom trawling on benthic community structure. Can J Fish Aquat Sci 59:1785-1795

Gerlach SA, Hahn AE, Schrage M (1985) Size spectra of benthic biomass and metabolism. Mar Ecol Prog Ser 26: 161-173

GESAMP (Group of Experts on the Scientific Aspects of Marine Pollution) (1994) Anthropogenic influences on sediment discharge to the coastal zone and environmental consequences. UNESCO-TOC, Paris

Gonzalez-Oreja JA, Saiz-Salinas JI (1999) Loss of heterotrophic biomass structure in an extreme estuarine environment. Estuar Coast Shelf Sci 48:391-399

Hanson JM (1990) Macroinvertebrate size distributions of two contrasting fresh water macrophyte communities. Freshw Biol 24:481-491

Hanson JM, Prepas EE, Mackay WC (1989) Size distribution of the macroinvertebrate community in a freshwater lake. Can J Fish Aquat Sci 46:1510-1519

Kerr SR, Dickie LM (2001) The biomass spectrum: a predator-prey theory of aquatic production. Columbia University Press, New York

Kormas KA, Kapiris K, Thessalou-Legaki M, Nicolaidou A (1998) Quantitative relationships between phytoplankton bacteria and protists in an Aegean semi-enclosed embayment (Maliakos Gulf Greece). Aquat Microb Ecol 15: 255-264

Kormas KA, Nicolaidou A, Thessalou-Legaki M (2003) Variability of environmental factors of an eastern Mediterranean Sea river influenced coastal system. Mediterr Mar Sci 4(1):67-77

Leaper R, Rafaelli D, Emes C, Manly B (2001) Constraints on body-size distributions: an experimental test of the habitat architecture hypothesis. J Anim Ecol 70:248-259

Milliman JD (2001) Delivery and fate of fluvial water and sediment to the sea: a marine geologist's view of European rivers. Sci Mar 65 (Suppl 2):121-132

Moodley L, Heip CHR, Middelburg JJ (1998) Benthic activity in sediments of the northwestern Adriatic Sea: sediment oxygen consumption macro- and meiofauna dynamics. J Sea Res 40:263-280

Pagola-Carte S (2004) ABC method and biomass size spectra: What about macrozoobenthic biomass on hard substrata?

Editorial responsibility: Howard I. Browman (Associate Editor-in-Chief), Storebø, Norway
Hydrobiologia 527:163-176

Peters RH (1983) The ecological implications of body size. Cambridge University Press, Cambridge

Peters RH, Wassenberg K (1983) The effect of body size on animal abundance. Oecologia 60:89-96

Poulos SE, Collins M, Shaw HF (1996) Deltaic sedimentation, including clay mineral deposition patterns, associated with small mountainous rivers and shallow marine embayments of Greece (SE alpine Europe). J Coast Res 12(4): 940-952

Quiroga E, Quinones R, Palma M, Sellanes J, Gallardo VA, Gerdes D, Rowe G (2005) Biomass size-spectra of macrobenthic communities in the oxygen minimum zone off Chile. Estuar Coast Shelf Sci 62:217-231

Ramsay PM, Rundle SD, Attrill MJ, Uttley MG, Williams PR, Elsmere PS, Abada A (1997) A rapid method for estimating biomass size spectra of benthic metazoan communities. Can J Fish Aquat Sci 52:1881-1892

Rasmussen JB (1993) Patterns in the size structure of littoral zone macroinvertebrate communities. Can J Fish Aquat Sci 50:2192-2207

Rhoads DC, Boesch DF, Zhican T, Fengshan X, Liqiang H, Nilsen KJ (1985) Macrobenthos and sedimentary facies on the Changjiang delta platform and adjacent continental shelf East China Sea. Cont Shelf Res 4:189-213

Ricciardi A, Bourget E (1998) Weight-to-weight conversion factors for marine benthic macroinvertebrates. Mar Ecol Prog Ser 163:245-251

Rodriguez MA, Magnan P (1993) Community structure of lacustrine macrobenthos: Do taxon-based and size-based approaches yield similar insights? Can J Fish Aquat Sci 50: 800-815

Saiz-Salinas JI, Ramos A (1999) Biomass size-spectra of macrobenthic assemblages along water depth in Antarctica. Mar Ecol Prog Ser 178:221-227

Schwinghamer P (1981) Characteristic size distributions of integral benthic communities. Can J Fish Aquat Sci 38: 1255-1263

Sheldon RW, Prakash A, Sutcliffe WH (1972) The size distribution of particles in the ocean. Limnol Oceanogr 17: $327-340$

Sprules WG, Munawar M (1986) Plankton size spectra in relation to system productivity, size and perturbation. Can J Fish Aquat Sci 43:1789-1794

Stead TK, Schmid-Araya JM, Schmid PE, Hildrew AG (2005) The distribution of body size in a stream community: one system, many patterns. J Anim Ecol 74(3):475-487

Strayer D (1986) The size structure of a lacustrine zoobenthic community. Oecologia 69:513-516

Turner SJ, Grant J, Pridmore RD, Hewitt JE, Wilkinson MR, Hume TM, Morissey DJ (1997) Bedload and water-column transport and colonization processes by post-settlement benthic macrofauna: Does infaunal density matter? J Exp Mar Biol Ecol 135:19-33

Warwick R (1993) Environmental impact studies on marine communities: pragmatical considerations. Aust J Ecol 18: $63-80$

Wijsman JWM, Herman PMJ, Gomoiu MT (1999) Spatial distribution in sediment characteristics and benthic activity on the northwestern Black Sea shelf. Mar Ecol Prog Ser 181:25-39

Zar JH (1984) Biostatistical analysis, 4th edn. Prentice Hall, Upper Saddle River, NJ

Submitted: November 17, 2005; Accepted: February 23, 2006 Proofs received from author(s): August 16, 2006 